\title{
Representasi Kehidupan Pada Naskah Drama Nyonya-Nyonya Karya Wisran Hadi
}

\section{Hairunnisa ${ }^{1 *}$ \\ Wika Soviana Devi ${ }^{1}$ \\ ${ }^{1}$ Universitas Muhammadiyah Jakarta, Tangerang Selatan, Banten *email: hairunnisaff@gmail.com}

Received: 30 Desember 2019

Accepted: 26 Maret 2020

Published: 26 Maret 2020

doi:

http://dx.doi.org/10.29405/imj.v2i2 .56

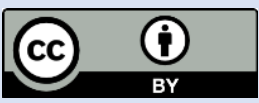

(C) 2020 Oleh authors. Lisensi Imajeri: Jurnal Pendidikan Bahasa dan Sastra Indonesia, Uhamka, Jakarta. Artikel ini bersifat open access yang didistribusikan di bawah syarat dan ketentuan Creative Commons Attribution (CC-BY) license.

(http://creativecommons.org/licens es/by/4.0/).

\begin{abstract}
Abstrak
Beberapa peristiwa memiliki keunikan tersendiri yang biasanya bisa menjadi inspirasi untuk membuat sebuah naskah drama. Dalam penulisan naskah drama, pengarang harus benar-benar memahami dan merasakan setiap adegan demi adegan, dialog demi dialog yang kemudian ditulis kembali menjadi sebuah karya sastra. Melalui pengalaman dan pengetahuan secara potensial memiliki berbagai macam bentuk representasi kehidupan. Objek yang diteliti adalah naskah drama Nyonya-Nyonya karya Wisran Hadi dengan menggunakan pendekatan sosiologi sastra. Penelitian ini menggunakan metode deskriptif. Metode deskriptif adalah pendekatan penelitian yang sumber datanya berupa kata-kata. Metode deskriptif ini bertujuan memaparkan hasil temuan pada proses penelitian berdasarkan tujuan penelitian. Hasil penelitian sosiologi sastra pada naskah drama NyonyaNyonya karya Wisran Hadi terdapat dua poin utama yaitu keteguhan terhadap norma yang berlaku dan kepercayaan pada kekuatan leluhur.
\end{abstract}

Kata kunci: sosiologi sastra; drama; realisme

\section{Abstract}

Some events have their own uniqueness which can usually be an inspiration to make a drama script. In writing a drama script, the author must truly understand and feel each scene after scene, dialogue after dialogue which is then re-written into a literary work. Through experience and knowledge potentially have various forms of life representation. The object studied was the drama script Nyonya-Nyonya by Wisran Hadi using a sociological approach to literature. This research uses a descriptive method. Descriptive method is a research approach whose source of data is in the form of words. This descriptive method aims to describe the findings of the research process based on the research objectives. The results of literary sociology research in the drama script Nyonya-Nyonya by Wisran Hadi, there are two main points, namely firmness to the prevailing norms and belief in ancestral power.

Keywords: sociology of literature; drama; realisme 


\section{PENDAHULUAN}

Pepatah lama mengatakan 'dunia adalah panggung sandiwara'. Dalam kehidupan sehari-hari pasti setiap manusia melalui begitu banyak peristiwa. Beberapa peristiwa memiliki keunikan tersendiri yang biasanya bisa menjadi inspirasi untuk membuat sebuah naskah drama. Dalam penulisan naskah drama, pengarang harus benar-benar memahami dan merasakan setiap adegan demi adegan, dialog demi dialog yang kemudian ditulis kembali menjadi sebuah karya sastra.

Secara umum pengertian drama adalah karya sastra yang merepresentasikan kehidupan manusia melalui lakon dan dialog. Sebelum mencapai proses pementasan drama, naskah drama menjadi yang paling pertama dipersiapkan. Waluyo (Anwar, dkk. 2018) menyatakan naskah drama adalah salah satu genre karya sastra yang sejajar dengan prosa dan puisi. Perbedaan naskah drama dengan prosa dan puisi, naskah drama berbentuk dialog yang berdasarkan atas konflik batin dan kemungkinan akan dipentaskan.

Setiap realita, fenomena, gejala, peristiwa, dan sebagainya dalam kehidupan bagi para pengarang merupakan bahan tulisan yang diolah di dunia imajinasinya untuk kemudian diekspresikan dalam bentuk karya satra, baik dalam bentuk puisi, prosa, maupun drama (Lisnawati,dkk: 2019:2). Drama yang dianggap sebagai rekaan kehidupan manusia selain mengandung sifat dan karakter tokoh juga memiliki persoalan yang menggambarkan kejadian dalam suatu lingkup tertentu.

Dari banyaknya karya sastra yang mengulik tentang kehidupan sosial, salah satunya yaitu drama Nyonya-Nyonya karya Wisran Hadi. Drama ini menceritakan tentang Tuan seorang pedagang barang antik yang sedang berteduh di rumah seorang Nyonya sambil menggerutu. Karena merasa tidak nyaman dengan kehadiran Tuan, si Nyonya mengusir Tuan dari teras rumahnya sebab ia tak ingin ada berita buruk tentang dirinya. Mengingat Nyonya ini hanya sendirian di rumah. Tuan yang bersikeras hanya ingin berteduh tanpa ada maksud lain meminta pengertian dari Nyonya hingga keduanya berargumen tentang pendiriannya masingmasing. Akhirnya Tuan terpaksa membeli empat buah marmer yang ia pijak untuk berteduh supaya Nyonya tidak mengusik dirinya sedang berteduh. Di samping itu, Nyonya berkonflik dengan tiga kemenakan Datuk suami Nyonya. Para kemenakannya itu berspekulasi bahwa Datuk telah memakan sendiri hasil penjualan tanah pusaka yang harusnya dibagi-bagi dengan mereka. Kemenakannya juga perfikir bahwa penyakit yang diderita Datuk akibat telah memakan uang hasil penjualan tanah pusaka tersebut.

Representasi kehidupan dalam naskah drama Nyonya-Nyonya karya Wisran Hadi merupakan naskah drama yang belum banyak dibahas sebagai objek penelitian yang menggunakan pendekatan sosiologi sastra. Naskah drama ini sebelumnya lebih banyak disoroti soal moralitas dan nilai-nilai budaya.oleh sebab itu, pokok dari penelitian ini adalah mengungkap gambaran keseharian yang sampai hari ini masih berlaku dan dipercayai beberapa masyarakat meskipun zaman sudah modern. 
Waluyo (Anwar, dkk. 2018) mengungkapkan bahwa naskah drama disebut juga sastra lakon. Sebagai salah satu genre sastra, naskah drama dibangun oleh struktur fisik (kebahasaan) dan struktur batin (semantik, makna). Wujud fisik sebuah naskah drama adalah dialog atau ragam tutur. Dialog merupakan unsur utama dalam naskah drama. Luxemburg, dkk (Hasanudin dalam Yurnelis, 2013) menyebutkan bahwa dialog di dalam drama merupakan bagian terpenting. Semua bentuk dialog yang dipentaskan dalam drama diperankan aktor dan aktris pada waktu yang sama. Dialog dalam drama menggambarkan konflik kepada penonton, dengan pembawaan yang khas dan sesuai dengan tokoh yang diperankan. Drama yang meyakinkan penonton seolah-olah itu adalah kenyataan disebut dengan drama realisme. Drama realisme hendak 'menipu' mata penonton bahwa realitas diatas pentas adalah realitas kehidupan sehari-hari. Maka aspek laku dan visual yang ditampilkan di atas pentas harus dihadirkan senatural mungkin. Lakon haruslah masuk akal, jujur, tanpa ditambah dan dikurangi (Stanilavsky dalam Novianto:2019).

Dalam realisme segala usaha dilakukan untuk menumbuhkan empati, penataan yang dibuat hampir persis dengan kehidupan sehari-hari, riasan dan lakon yang diperankan seolaholah yang sebenarnya terjadi.

Sejalan dengan konsep drama realisme yang dibuat sama persis dengan kehidupan sehari-hari, sosiologi sastra menjadi pendekatan yang tepat untuk menganalisis representasi kehidupan yang terdapat dalam naskah drama Nyonya-Nyonya karya Wisran Hadi. Menurut Damono (Purnamasari, dkk. 2017) sosiologi sastra adalah pendekatan yang memahami kultur yang terkandung. Berpedoman pada analisis teks untuk mengetahui strukturnya lalu dipergunakan untuk mehami gejala sosial di luar sastra.

Wellek dan Warren (2016) menyatakan pembahasan hubungan sastra dan masyarakat biasanya bertolak padadari frasa De Bonald bahwa "sastra adalah ungkapan perasaan masyarakat". Jika sastra hanya menunjukkan beberapa aspek realita sosial ungkapan itu terlalu dangkal dan samar. Lebih jelas lagi kalau dikatakan bahwa sastra mencerminkan dan mengekspresikan hidup.

Sosiologi sastra (Devi, 2019) merupakan karya sastra yang melihat hubungannya dengan kenyataan. Kenyataan ini mengandung arti yang cukup luas, yaitu sesuatu yang berada di luar sastra namun masih diacu oleh sastra itu sendiri. Poin penting yang dikenakan karya sastra adalah 'kebenaran', penggambaran atau yang hendak digambarkan.

Faruk (Devi, 2019) memberi pengertian bahwa sosiologi sastra sebagai ilmu sekaligus objek mengenai manusia dan kehidupan bermasyarakat mengenai kegiatan sosial berikut proses yang mengikutinya. Selanjutnya sosiologi juga dianggap untuk menjawab perihal bagaimana masyarakat dimungkinkan, bagaimana prosesnya dan mengapa manusia itu bertahan.

Sejalan dengan beberapa teori di atas, Ratna (Devi, 2019) memaparkan beberapa hal yang harus dipertimbangkan mengapa sastra memiliki kaitan erat dengan masyarakat dan dengan demikian harus diteliti dalam kaitannya dengan masyarakat sebagai berikut: (1) karya sastra ditulis oleh pengarang, diceritakan oleh tukang cerita, disalin oleh penyalin, ketiganya adalah anggota masyarakat, (2) karya sastra hidup dalam masyarakat, meyerap aspek-aspek kehidupan yang terjadi dalam masyarakat yang pada gilirannya difungsikan masyarakat, (3) medium karya sastra baik lisan maupun tulisan melalui kompetensi masyarakat dengan sendirinya mengandung masalah kemasyarakatan, (4) dalam karya sastra mengandung estetik, etika bahkan juga logika, (5) karya sastra adalah hakikat intersubjektivitas, masyarakat menemukan citra dirinya dalam suatu karya. 


\section{METODE}

Penelitian menggunakan metode deskriptif. Metode deskriptif adalah pendekatan penelitian yang sumber datanya berupa kata-kata. Metode deskriptif ini bertujuan memaparkan hasil temuan pada proses penelitian berdasarkan tujuan penelitian. Merriam (Fatni, 2017) menyatakan sifat dari penelitian kualitatif adalah penyajian data yang berbentuk narasi atau deskripsi, lebih dominan ke kata-kata daripada angka. Sehingga, data penelitian ini akan dijelaskan oleh penelitian secara deskriptif.

Objek yang diteliti adalah naskah drama Nyonya-Nyonya karya Wisran Hadi dengan menggunakan pendekatan sosiologi sastra. Penelitian ini bertujuan untuk mengungkap poinpoin representasi sosial dalam naskah drama tersebut. Teknik pengumpulan data dilaksanakan melalui beberaa tahap, yaitu: (1) menentukan objek penelitian dan fokus penelitian, (2) membaca dan memahami objek penelitian, (3) mencari pendekatan dan toeri yang cocok dianalisis dalam objek penelitian, (4) mengidentifikasi objek penelitian melalui pendekatan dan teori yang sudah ditetapkan, (5) menganalisis objek penelitian, (6) memasukan hasil analisis.

\section{HASIL DAN PEMBAHASAN}

Berdasarkan penelitian yang telah dilakukan terdapat dua poin utama sosiologi sastra dalam naskah drama Nyonya-Nyonya karya Wisran Hadi, dengan rincian sebagai berikut:

\section{Keteguhan Terhadap Norma yang Berlaku}

Untuk membahas permasalahan mengenai keteguhan terhadap norma yang berlaku termasuk ke dalam potret kenyataan sosial, penulis dalam melakukan perwujudan terhadap drama Nyonya-Nyonya tidak terlepas dari pernyataan A.Teeuw (Winarni, ) dalam bukunya membaca dan menilai sastra bahwa sebuah teks sastra (salah satunya drama) hadir tidak berangkat kekosongan atau kevakuman belaka.

Potret kenyataan sosial merupakan istilah lain dari sosiologi sastra. Menurut Wellek dan Warren (Devi, 2019) pendekatan sosiologi sastra bertujuan untuk mempelajari sastra sebagai dasar dari kenyataan sosial yang digambarkan. Sedangkan menurut Ratna (Devi, 2019:139) sosiologi sastra adalah hubungan dua arah (dialektik) antara sastra dengan masyarakat.

TUAN : Nyonya di dalam rumah mendapatkan kehangatan, sedangkan saya di luar mendapat kedinginan. Apa salahnya Nyonya membagi-bagikan kehangatan Nyonya itu sedikit dengan mengizinkan saya berdiri di teras ini. Nyonya akan dituduh orang kejam, bila Nyonya mengusir seorang yang sedang kedinginan.

NYONYA : Kejam atau tidak, yang penting aku harus menjaga nama baikku. Coba Tuan piker. Ibuku sedang ada di rumah sakit. Bila seorang istri sendirian lalu didatangi lelaki, Tuan tentu tahu ekornya, bukan? (Hadi, 1982)

Penulis melakukan perwujudan yang dikaitkan dengan pengalaman dan kebudayaan yang selama ini berlaku. Potret kehidupan sosial yang direpresentasikan oleh tokoh nyonya dalam Nyonya-Nyonya dilakukan kepada tuan. Perilaku dominan yang ditujukan nyonya kepada tuan adalah penolakan kehadiran tuan yang hanya berteduh di teras rumahnya. Karena 
ia takut akan menjadi buah bibir masyarakat akan kehadiran tuan yang berdiri di depan rumahnya. Mengingat ia hanya sendirian di rumah.

Ekor sendiri diartikan sebagai akibat dari kejadian atau keadaan sebelumnya (peristiwa). Nyonya tidak ingin namanya tercoreng di mata masyarakat karena kehadiran tuan. Bagi masyarakat kehadiran perempuan dan laki-laki yang bukan suami istri di satu rumah akan menimbulkan gosip yang tidak-tidak. Karena itu akan menjadi momok dan menjadi masalah yang rumit.

$\begin{array}{ll}\text { NYONYA } & \text { : Pergi! itu sudah pembayaran yang pantas! } \\ \text { TUAN } & \text { : Malaria saya bagaimana, Nyonya!? } \\ \text { NYONYA } & \text { : Bukan urusanku! } \\ \text { TUAN } & \text { : Benar juga firasat saya. Di mana pun juga di atas dunia ini, rumah } \\ & \text { mewah selalu tidak ramah pada tamu! } \\ \text { NYONYA } & \text { : Tuan jangan bicara macam-macam di sini. Rumahku yang mewah ini } \\ & \text { dibuat bukan untuk kepentingan ramah tamah, tapi untuk kesenanganku } \\ & \text { dengan suamiku! Ah, ekornya Tuan. Ekornya, kritik Tuan itu sangat } \\ & \text { menggelisahkan pemilik rumah mewah lainnya. Pergilah, Tuan! Pergi. } \\ & \text { aku benci dengan orang-orang yang suka mengkritik, apalagi hanya } \\ & \text { unuk melindungi kepentingannya sendiri. }\end{array}$

Jika ditinjau dari segi ekonomi, sebagian masyarakat berpendapat jika orang yang tinggal di rumah mewah tidak 'ramah', apalagi jika orang tersebut tinggal di perumahan. Sebab orang yang tinggal di perumahan memiliki satpam yang penjagaannya ketat dan sudah diperintahkan untuk tidak asal menerima tamu yang tidak jelas keperluan atau identitasnya. Dialog tuan di atas merupakan keadaan sosial yang terjadi. Meskipun ia sudah memohon dengan baik dan ia khawatir akan penyakit malaria yang dideritanya, nyonya tidak mengubris apapun perkataan tuan. Nyonya juga takut akan menjadi bahan gunjingan masyarakat lewat perkataannya yang membela dirinya sendiri.

\section{Kepercayaan Pada Kekuatan Leluhur}

Menurut Devi (2019) sebuah karya sastra tidak pernah berangkat dari kekosongan sosial. Artinya karya sastra ditulis berdasarkan kehidupan sosial masyarakat tertentu dan menceritakan kebudayaan-kebudayaan yang melatarbelakanginya. Grebsten (Damono dalam Devi, 2019) menyatakan karya sastra tidak dapat dipahami secara lengkap apabila terpisah dengan kebudayaan yang melatarbelakanginya. Karya sastra itu sendiri merupakan objek yang selalu berhubungan dengan budaya. Bagaimanapun karya sastra bukanlah suatu karya yang berdiri sendiri.

PONAKAN A: Aku khawatir penyakit yang diderita datuk selama ini disebabkan kutukan nenek moyang.

NYONYA : Kutukan, katamu?

PONAKAN A: Ya. Hampir semua orang yang memakai uang dari penjualan tanah pusaka mendapat penyakit yang aneh-aneh. (Hadi, 1982) 
Pada saat naskah tersebut ditulis, tentu kepercayaan pada kekuatan leluhur masih sangat kental dan masih dijunjung tinggi. Ponakan A (masyarakat) masih memegang teguh kepercayaan (budaya) yang berlaku di tempat tinggalnya. Kepercayaan tentang petuah dan akibat yang ditimbulkan jika melakukan suatu tindakan yang tercela. Pada naskah tersebut diceritakan bahwa ponakan A berspekulasi bahwa datuknya meninggal akibat memakan uang hasil penjualan tanah pusaka (warisan)

Menurut kebudayaan Minang, warisan dibagi menjadi dua jenis, yaitu pusaka tinggi dan pusaka rendah. Pusaka tinggi adalah warisan yang telah ada secara turun-temurun dan dilanjutkan pada generasi sebelumnya. Pusaka tinggi ini dibagi berdasarkan keputusan datuk tertua di suatu kaum. Sedangkan pusaka rendah dibagi berdasarkan aturan agama yang dianut (Wikipedia).

Jika ditinjau kembali terbitnya Nyonya-nyonya pada 1982 mencerminkan kehidupan sosial yang masih kental dan takluk pada adat yang berlaku. Masyarakat masih mempercayai peninggalan leluhurnya walaupun sebenarnya belum tentu benar adanya.

\section{SIMPULAN}

Naskah drama nyonya-nyonya karya Wisran Hadi ditulis pada tahun 1982. Naskah ini tergolong ke dalam drama realis. Drama realisme mencoba meyakinkan kepada penonton bahwa peristiwa yang dihadirkan di atas pentas adalah seolah-olah nyata. Drama realisme hendak 'menipu' mata penonton bahwa realitas diatas pentas adalah realitas kehidupan seharihari.

Drama ini dikaji menggunakan teori sosiologi sastra yang hasilnya memiliki dua poin utama yakni keteguhan terhadap norma yang berlaku dan kepercayaan pada kekuatan leluhur.

\section{DAFTAR PUSTAKA}

Anwar, Febrina. dkk. (2018). "Kritik Sosial Dalam Naskah Drama Alangkah Lucunya Negeri Ini Karya Deddy Mizwar”. Jurnal Bahasa dan Sastra. Vol. 3. No. 6

Devi, Wika Soviana. (2019). Teori Sastra. Jakarta. CV Al Chalief.

Fatni. (2017). "Analisis Makna Teks Lagu Album Wakil Rakyat Ciptaan Iwan Fals Melalui Pendekatan Hermeneutika”. Sulawesi Tengah. Jurnal Bahasa dan Sastra vol. 2. No. 1.

Hadi, Wisran. (2010). Nyonya-nyonya. http://naskahdrama-rps.blogspot.com/2010/08/nyonyanyonya-wisran-hadi-html?m=1 . Diakses pada 13 November 2019 pukul 10.36.

Lisnawati, Lis, Titin Setiartin, \& Ai Siti Nurjamilah. (2019). "Drama "Lelakon Raden Bei Surio Retno" Karya F. Wiggers Dalam Perspektif Pendekatan Struktural Dan Pendekatan Sosiologis". Jurnal Metabasa, Volume 1, No. 1, Juni 2019.

Novianto, Wahyu. (2019). "Dramaturgi Teater Realisme Siasat Dramatik dan Artistik Mencipta Ilusi Realitas. Surakarta”. Jurnal Acintya Vol. 10. No. 2 .

Purnamasari, Ayu. dkk. (2017). "Analisis Sosiologi Sastra Dalam Novel Bekisar Merah Karya Ahmad Tohari. Jurnal Ilmu Budaya”. Vol. 1. No. 2

Wellek, Rene. dkk (2016). Teori Kesusastraan. Jakarta. Gramedia Pustaka Utama.

Yurnelis, dkk. (2013). "Peningkatan Keterampilan Menulis Naskah Drama Melalui Pendekatan Pembelajaran Kontekstual Siswa Kelas VIII RSBI-1 SMP N 12 Padang”. Jurnal Bahasa, Sastra dan Pembelajaran. Vol. 1 No. 2 